\title{
棉倩斑病細菌のバクテリオフアーデユに關する㸴究
}

\section{II 變異菌とファーデニの關傒に就て}

\author{
岡 部 德 夫 \\ (壹北帝國大學理農學部植物病理學教宝) \\ (昭 和 13 年 10 月 17 日受領)
Norio OKABE: - Bacteriophage in Reation to
Bactorium malvacearum.

II. Relation betwen Variants and Phage.*

梢の的病細菌 Bact. malvacearum は一般の稙物病原細菌之違つた非常に 特徽あるColony を肉汁寒天唔養基上に形成する。此の特性は㞗々病斑に檤件 する腐生性の黃色細菌と區別するのに役立つものであるが，時には全く別種の 練菌でばなかと考人られる程著しく異なるすのを形成することがある。本菌 の特徽は培盖後 2-3 日にして現れ，其後は潮次に不明嘹となり，数日後には 全く消失するもので Colony の質の不均一性が原因して現れる樣である。E． F. SMITH はRose-window を思はせる此の特異なる Colony に對して“Windowed”Colony なる名稱を付して居る。“Windowed” Colony は少くとも 現在知られて居る範園に於ては角玟病菌にのみ見られる特徴ではあるが，本菌 の Colony は必ずしも凡て window を有するとは限らず，中には全く有さな


の大きさ，位置，方向，形等に差異があり，是等は發育の初期に䄲て現れる一 時的特性ではあるが，夫ふの型によつて一定し，或例外を除いて戀化しないる のである。

著者は本島に於て分離せる Bact. malvacearum の2系統を此の特性に低つ

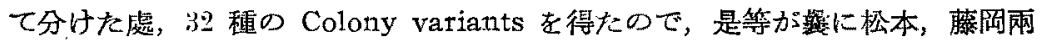

* From the Phytopathological Laboratory, Taihoku Imperial University, Formosa, Japan. 
氏によつて分睢された「バクデリフプーヂさ」と如何なる關係にあるかを研 究中の趋，偶々昭和 13 年 8 月 11 日帝國軍人の一貝としてOOされ同月 15 日 ○○聯隊人○○することになり一特研究を中止するの已むなき狀態に至つた。

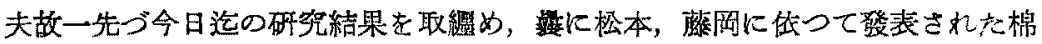
の角玟病細菌のバクテリオフアーデュに關する研究の纑䇉として，茲に報告す る次第である。

\section{Bact. malvaceanum $の$ Colony 戀異に就}

本菌の戀異に就ては少数の人ネが断片的な研究を發表して居るに過ぎない。 E. F. SMiтн(15) は 1920 年其著 Bacterial Diseases of plants 中に Colony の寫㣀を數葉揭け゚て居るが，是を見ると本囷の Colony には数種類あることが 知られる。1928 年 S. H. EVELYN(1) は Barbados に於ける棉の角斑病を研 究し，是の病原菌に對し，var. barbadense なる名稱を付して居るか，不幸に も其報告を手にすることが出本ないので詳細な點に就いて注知る由もない。 1930 年 STOUGHTON ${ }^{(6)}$ は Bact. malvacearum 中には少くをも3 種の dis-

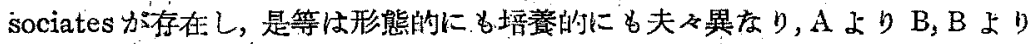

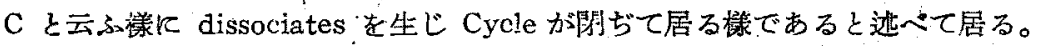
1931 年には R. E. MASSEY(2) が寄主上り分離せる細菌は何れも一樣に smooth で病原性を有するが，培盖をして行くと次第化種々疗る戀異菌を生ずると報告 してるる。1932 年 STOUGHTON(7) は病原性が異なり培養的にも相異する数種の dissociates を得，强き病原性の Strainさりは non-virulent 菌を生じ，佩是 よりは文培盖的に異なる virulent菌を生ずるこ報告して居る。MASSEY (3)は 1934年 rough co'ony form 恔病原性を有さないが, smooth colony form は 病原性を有する。R-form 菌にバクテリオフアーヂュを作用せしむると永久的 透明起し，之に反し smooth form 菌は一時的透明を起すに過ぎいと逝べ て居る。

以上に逝べた如く，本菌には種々の變異菌が認められて居るが，夫等の性状

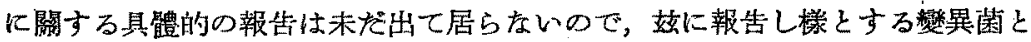
此较することは出來ないけれと，是等の队には上速の變異菌と同一のものがあ ると侤へられる。 
本研究に使用せる細菌は次の 2 稙類である。

Culture No. 427 1931. 年 9 月 25 日

著者分離

Culture No. 450

1937 年 8 月

藤岡分離

蹾異薂の分離の方法

前記の兩細菌を Bouillon 或は potato dextrose solutionに培養し， 24 時 間後，3 日後，5 日後，10日後，夫及肉汁寒天 (Plate Culture に移植し, (溫 度は $25^{\circ}$ 一 $\left.28^{\circ} \mathrm{C}\right) 2$ 日目乃至 3 日目に出現せる Colony を援大鏡にて檢し，形 熊の異なるものを夫く别ねに培養し，倘是等各種の Colony types は更に同樣 液體培養を試み，再分離をなすと共に，其際生ぜる別の新型分離用にも供した。

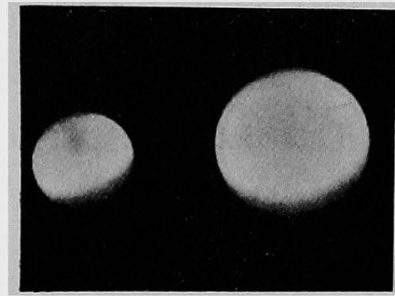

$A$

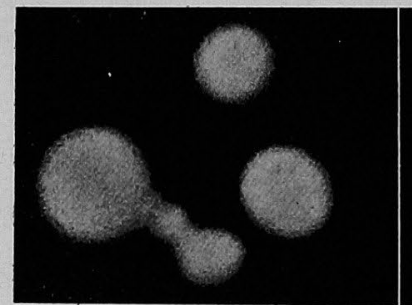

$\mathrm{D}$

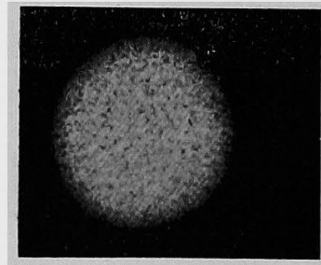

G

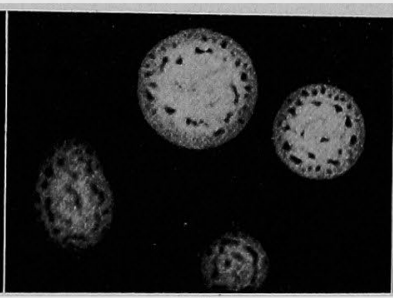

B

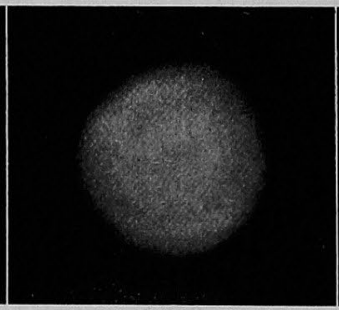

E

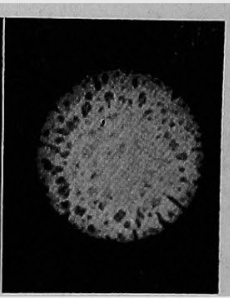

C

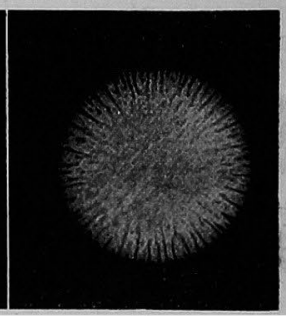

F

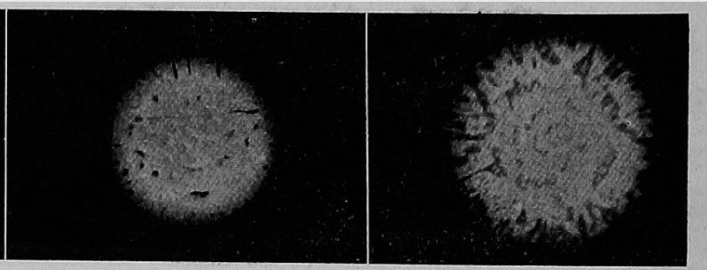

H

Fig 1. 棉角斑病菌の肉汁寒天上に於ける形態 (Cu1ture No. 427.) 變異菌のColony の特徵

上迅の方法に依り得たる變異菌が中性の成汁寒天平面培養基上に示す形狀は

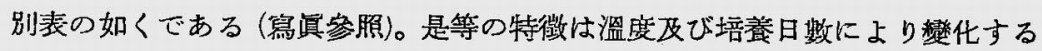




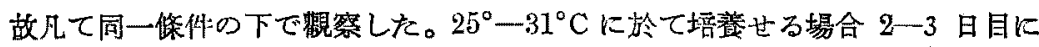
最も差違明瞕にして溫度の上䒜，日数の涇過は特徴を不明暸ならしむ。大部分



の Colony form を生じ，更に二つ以上に分かれる。

第 I 表 Culture No. 427 上り得たる孌異菌の $31^{\circ} \mathrm{C}$ に於ける 2 日目の形勥

Tab. 1. Morphological characters of the 2 day-culture $\left(31^{\circ} \mathrm{C}\right)$ of variants derived from strain 427

\begin{tabular}{|c|c|c|c|c|}
\hline Type & $\begin{array}{c}\text { Diameter } \\
(\mathrm{mm})\end{array}$ & Shape & Optical characters & Marking \\
\hline A & 1.5 & $\begin{array}{l}\text { Round, } \\
\text { convex, } \\
\text { entire margin }\end{array}$ & $\begin{array}{l}\text { Translucent, } \\
\text { pearly lustre, } \\
\text { Barium yellow }\end{array}$ & No marking \\
\hline B & 1.0 & $\begin{array}{l}\text { Round, } \\
\text { flatly convex, } \\
\text { entire margin }\end{array}$ & $\begin{array}{l}\text { Transparent, } \\
\text { pale chalcedony } \\
\text { yellow, } \\
\text { center : cream color, } \\
\text { margin : Etain blue }\end{array}$ & Large window \\
\hline $\mathrm{C}$ & 1.5 & $\begin{array}{l}\text { Round, } \\
\text { convex, } \\
\text { entire margin }\end{array}$ & $\begin{array}{l}\text { Trapslucent, } \\
\text { Barium yellow }\end{array}$ & $\begin{array}{l}\text { Many window, } \\
\text { rimose in margin }\end{array}$ \\
\hline $\mathrm{D}$ & 1.0 & $\begin{array}{l}\text { Round, } \\
\text { convex, } \\
\text { entrie margin }\end{array}$ & $\begin{array}{l}\text { Translucent, } \\
\text { pale chalcedony } \\
\text { yellow, } \\
\text { periphery : Etain } \\
\text { blue }\end{array}$ & $\begin{array}{l}\text { Small window in } \\
\text { periphery }\end{array}$ \\
\hline$E$ & 1.0 & $\begin{array}{l}\text { Flatly convex, } \\
\text { round, } \\
\text { entire margin }\end{array}$ & $\begin{array}{l}\text { Transparent, } \\
\text { pale itmine green, } \\
\text { sligh tly pearly } \\
\text { lustre }\end{array}$ & No marking \\
\hline $\mathrm{F}$ & 1.5 & $\begin{array}{l}\text { Flatly convex, } \\
\text { round, } \\
\text { entire margin }\end{array}$ & $\begin{array}{l}\text { Transparent; } \\
\text { p le chalcedony } \\
\text { yellow }\end{array}$ & $\begin{array}{l}\text { Chrysanthemum- } \\
\text { like marking }\end{array}$ \\
\hline $\mathrm{G}$ & 1.5 & $\begin{array}{l}\text { Round, } \\
\text { flatly convex, } \\
\text { entire margin }\end{array}$ & $\begin{array}{l}\text { Transparent, } \\
\text { pale chalcedony } \\
\text { yellow }\end{array}$ & $\begin{array}{l}\text { Lace-like marking } \\
\text { with small window }\end{array}$ \\
\hline $\mathrm{H}$ & 1.0 & $\begin{array}{l}\text { Round, } \\
\text { flatly convex, } \\
\text { entire margin }\end{array}$ & $\begin{array}{l}\text { Transparent, } \\
\text { pale chalcedony } \\
\text { yellow }\end{array}$ & $\begin{array}{l}\text { Window, } \\
\text { rimose in periphery }\end{array}$ \\
\hline$I$ & 1.5 & $\begin{array}{l}\text { Round, } \\
\text { fratly convex, } \\
\text { entire margin }\end{array}$ & $\begin{array}{l}\text { Translucent, } \\
\text { light chalcedony } \\
\text { yellow }\end{array}$ & Window \& striping \\
\hline
\end{tabular}




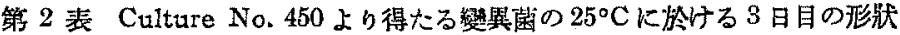

Tab. 2. Morphological characters of the 3 day-culture $\left(25^{\circ} \mathrm{C}\right)$ of variants derived from strain 450

\begin{tabular}{|c|c|c|c|c|}
\hline Type & $\begin{array}{c}\text { Diameter } \\
(\mathrm{mm})\end{array}$ & Shape & Optical characters & Marking \\
\hline$A$ & $1.5-2.5$ & $\begin{array}{l}\text { Round, convex, } \\
\text { entire, thin. } \\
\text { margin }\end{array}$ & $\begin{array}{l}\text { Translucent, } \\
\text { pale chalcedony } \\
\text { yellow, } \\
\text { pearly luster }\end{array}$ & No marking \\
\hline $\mathrm{B}$ & $0.5-0.8$ & $\begin{array}{l}\text { Round, raised, } \\
\text { lacerate margin }\end{array}$ & $\begin{array}{l}\text { Translucent, } \\
\text { Barium yellow }\end{array}$ & Rugose surface \\
\hline $\mathrm{C}$ & $1.5-2.0$ & $\begin{array}{l}\text { Round, } \\
\text { convex, entire, } \\
\text { thin margin }\end{array}$ & $\begin{array}{l}\text { Translucent, } \\
\text { Barium yellow, } \\
\text { pearly lustre } \\
\text { in" periphery }\end{array}$ & $\begin{array}{l}\text { Slightly cross } \\
\text { hatching in } \\
\text { periphery }\end{array}$ \\
\hline $\mathrm{D}$ & $1.5-2.5$ & $\begin{array}{l}\text { Round, } \\
\text { flatly convex, } \\
\text { entire, thin } \\
\text { margin }\end{array}$ & $\begin{array}{l}\text { Transparent, } \\
\text { pale chalcedony } \\
\text { yellow }\end{array}$ & $\begin{array}{l}\text { Filamentous } \\
\text { marking, window } \\
\text { usually absent }\end{array}$ \\
\hline $\mathbf{E}$ & $1.0-1.5$ & $\begin{array}{l}\text { Round, convex, } \\
\text { entire, thin } \\
\text { margin }\end{array}$ & $\begin{array}{l}\text { Transparent, } \\
\text { pale chalcedony } \\
\text { yellow, opaline } \\
\text { green by reflected } \\
\text { light }\end{array}$ & $\begin{array}{l}\text { Cross-hatching } \\
\text { with pearly } \\
\text { lustre }\end{array}$ \\
\hline $\mathrm{F}$ & $1.0-2.0$ & $\begin{array}{l}\text { Round, convex, } \\
\text { entire, thin } \\
\text { margin }\end{array}$ & $\begin{array}{l}\text { Translucent, } \\
\text { grayish white }\end{array}$ & $\begin{array}{l}\text { Few windows in } \\
\text { margin }\end{array}$ \\
\hline $\mathrm{G}$ & 0.6 & $\begin{array}{l}\text { Round, raised, } \\
\text { lacerate margin }\end{array}$ & $\begin{array}{l}\text { Translucent, } \\
\text { Barium yellow, } \\
\text { Etain blue by } \\
\text { transmitted light }\end{array}$ & Rugose surface \\
\hline $\mathrm{H}$ & $1.0-2.0$ & $\begin{array}{l}\text { Round, raised, } \\
\text { lacerate margin }\end{array}$ & $\begin{array}{l}\text { Translucent, } \\
\text { Barium yellow, } \\
\text { grayish white by } \\
\text { transmitted light }\end{array}$ & Rugose surface \\
\hline I & $1.0-2.0$ & $\begin{array}{l}\text { Round, } \\
\text { convex, lacerate } \\
\text { margin }\end{array}$ & $\begin{array}{l}\text { Translucent, } \\
\text { pale chalcedony } \\
\text { yellow }\end{array}$ & Wrinkled marking \\
\hline$J$ & $0.8-1.0$ & $\begin{array}{l}\text { Round, raised, } \\
\text { lacerate margin }\end{array}$ & $\begin{array}{l}\text { Transparent, } \\
\text { pale dull green- } \\
\text { yellow }\end{array}$ & -Granular marking \\
\hline $\mathrm{K}$ & $1.5-2.0$ & $\begin{array}{l}\text { Round, convex, } \\
\text { entire, thin } \\
\text { margin }\end{array}$ & $\begin{array}{l}\text { Translucent, } \\
\text { pale chalcedony } \\
\text { yellow }\end{array}$ & $\begin{array}{l}\text { Radiate window, } \\
\text { center rugose }\end{array}$ \\
\hline $\mathbf{L}$ & 0.8 & $\begin{array}{l}\text { Round, convex, } \\
\text { entire }\end{array}$ & $\begin{array}{l}\text { Translucent, } \\
\text { Barium yellow }\end{array}$ & No marking \\
\hline
\end{tabular}






\begin{tabular}{|c|c|c|c|c|}
\hline Type & $\left|\begin{array}{c}\text { Diameter } \\
(\mathrm{mm})\end{array}\right|$ & Shape & Optical characters & Marking \\
\hline $\mathrm{M}$ & $1-1.5$ & $\begin{array}{l}\text { Round, convex, } \\
\text { entire }\end{array}$ & $\begin{array}{l}\text { Translucent, } \\
\text { Barium yellow }\end{array}$ & $\begin{array}{l}\text { Striate marking } \\
\text { in periphery }\end{array}$ \\
\hline $\mathrm{N}$ & $1-1.5$ & $\begin{array}{l}\text { Round, convex, } \\
\text { entire, thin } \\
\text { margin }\end{array}$ & $\begin{array}{l}\text { Transparent, } \\
\text { Barium yellow }\end{array}$ & Fish-scale marking \\
\hline $\mathrm{O}$ & $1-1.5$ & $\begin{array}{l}\text { Round, flatly } \\
\text { convex, entire, } \\
\text { thin margin }\end{array}$ & $\begin{array}{l}\text { Trapslucent; pale } \\
\text { dull green-yellow, } \\
\text { margin Etain blue }\end{array}$ & $\begin{array}{l}\text { Lace-like growth } \\
\text { with window }\end{array}$ \\
\hline $\mathrm{p}$ & 1.0 & $\begin{array}{l}\text { Round, flatly } \\
\text { convex, entire, } \\
\text { thin margin }\end{array}$ & $\begin{array}{l}\text { Translucent, } \\
\text { pale dull green- } \\
\text { yellow }\end{array}$ & $\begin{array}{l}\text { Lace-like growth } \\
\text { with large window. }\end{array}$ \\
\hline$Q$ & $1.5-2.5$ & $\begin{array}{l}\text { Round, flatly } \\
\text { convex, entire, } \\
\text { thin margin }\end{array}$ & $\begin{array}{l}\text { Translucent, pale } \\
\text { chalcedony yellow, } \\
\text { Fearly lustre }\end{array}$ & $\begin{array}{l}\text { No or slightly } \\
\text { concentric mar* } \\
\text { king. }\end{array}$ \\
\hline $\mathbf{R}$ & $1-1.5$ & $\begin{array}{l}\text { Round, convex, } \\
\text { entire, thin } \\
\text { margin }\end{array}$ & $\begin{array}{l}\text { Translucent, } \\
\text { pale dull green } \\
\text { yellow }\end{array}$ & Radiate window \\
\hline$S$ & $1-2.0$ & $\begin{array}{l}\text { Round, convex, } \\
\text { entire, thin } \\
\text { margin }\end{array}$ & $\begin{array}{l}\text { Translucent, } \\
\text { pale dull green } \\
\text { yellow }\end{array}$ & $\begin{array}{l}\text { Centre rugose, } \\
\text { window especially } \\
\text { in periphery }\end{array}$ \\
\hline $\mathrm{T}$ & $1-1.8$ & $\begin{array}{l}\text { Round, convex, } \\
\text { entire margin }\end{array}$ & Ditto & $\begin{array}{l}\text { Lace-like growth } \\
\text { with rugose } \\
\text { surface }\end{array}$ \\
\hline $\mathrm{U}$ & $1.5-2.5$ & $\begin{array}{l}\text { Round, convex, } \\
\text { lucerate margin }\end{array}$ & $\begin{array}{l}\text { Transparent, } \\
\text { pale chalcedony } \\
\text { yellow }\end{array}$ & $\begin{array}{l}\text { Lace-like growth, } \\
\text { window in } \\
\text { periphery }\end{array}$ \\
\hline$V$ & $1.5-2.0$ & $\begin{array}{l}\text { Round, convex, } \\
\text { radiately fringed }\end{array}$ & $\begin{array}{l}\text { Translucent, } \\
\text { pale chalcedony } \\
\text { yellow }\end{array}$ & $\begin{array}{l}\text { No window, } \\
\text { centre slightly } \\
\text { rugose }\end{array}$ \\
\hline $\mathrm{W}$ & $1-1.8$ & $\begin{array}{l}\text { Round, convex, } \\
\text { undulate }\end{array}$ & $\begin{array}{l}\text { Transiucent, pale } \\
\text { chalcedony yellow }\end{array}$ & $\begin{array}{l}\text { No window, } \\
\text { rugose surface }\end{array}$ \\
\hline
\end{tabular}

II 變異菌に對するフアーギニの作用

最に松本，藤同(4)に位つて Bact. malvacearum のバクテリオフアーヂニは 他の植物病原菌に溶菌作用を示さら゙ることを報击されたが，上逃の如くにして 得たる變異菌が果してフアーヂニの作用を受けるや否やは興味ある事項にして， 次の如き方法によつて賽驗を行つた。

A. 各變異菌を potato dextrose solution に植え, 同時にフアーヂニを接 種せる場合 


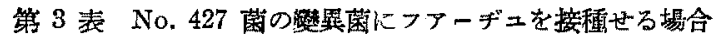

Tab. 3. Phagic activity against the variants of strain 427 .

\begin{tabular}{|c|c|c|c|c|c|c|c|c|c|}
\hline \multirow{3}{*}{ Type } & \multicolumn{4}{|c|}{ Turbidity of cultures } & \multirow{3}{*}{ Type } & \multicolumn{4}{|c|}{ Turbidity of ctultures } \\
\hline & \multicolumn{2}{|c|}{ After 24 hours } & \multicolumn{2}{|c|}{ After 3 days } & & \multicolumn{2}{|c|}{ After 24 hours } & \multicolumn{2}{|c|}{ After 3 days } \\
\hline & $\begin{array}{l}\text { Bact. }+ \\
\text { phage }\end{array}$ & $\begin{array}{l}\text { Bact. } \\
\text { per se }\end{array}$ & $\begin{array}{l}\text { Bact. }+ \\
\text { phage }\end{array}$ & $\begin{array}{l}\text { Bact. } \\
\text { per se }\end{array}$ & & $\begin{array}{l}\text { Bact. }+ \\
\text { phage }\end{array}$ & $\begin{array}{l}\text { Bact. } \\
\text { per se }\end{array}$ & $\begin{array}{l}\text { Bact. }+ \\
\text { phage }\end{array}$ & $\begin{array}{l}\text { Bact: } \\
\text { per se }\end{array}$ \\
\hline A & 1 & 1 & 4 & 4 & $\mathrm{~F}$ & 1 & $I$ & 4 & 4 \\
\hline B & 1 & 1 & 3 & 3 & G & 1 & 1 & 3 & 3 \\
\hline $\mathrm{C}$ & 1 & $I$ & 3 & 3 & $\mathrm{H}$ & 1 & 1 & 4 & 4 \\
\hline$D$ & 1 & 1 & 4 & 4 & 1 & 1 & 1 & 4 & 4 \\
\hline $\mathrm{E}$ & 1 & $\mathbf{I}$ & 3 & 3 & & & & & \\
\hline
\end{tabular}

數字は Turbidity の程度を示し，数字の大なる程大なり

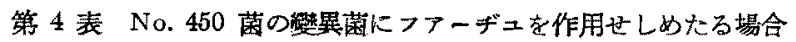

Tab. 4. Phagic activity against the variants of strain 450 .

\begin{tabular}{|c|c|c|c|c|c|c|c|c|c|c|c|c|c|}
\hline \multirow{3}{*}{ Type } & \multicolumn{6}{|c|}{ Turbidity of cultures } & \multirow{3}{*}{ Type } & \multicolumn{6}{|c|}{ Turbidity of cultures } \\
\hline & \multicolumn{2}{|c|}{$\begin{array}{l}\text { After } 24 \\
\text { hours }\end{array}$} & \multicolumn{2}{|c|}{$\begin{array}{l}\text { After } 3 \\
\text { days }\end{array}$} & \multicolumn{2}{|c|}{$\begin{array}{l}\text { After } 7 \\
\text { days. }\end{array}$} & & \multicolumn{2}{|c|}{$\begin{array}{l}\text { After } 24 \\
\text { hours }\end{array}$} & \multicolumn{2}{|c|}{$\begin{array}{l}\text { After } 3 \\
\text { days }\end{array}$} & \multicolumn{2}{|c|}{$\begin{array}{l}\text { After } 7 \\
\text { days. }\end{array}$} \\
\hline & $\begin{array}{l}\text { Bact. } \\
+ \text { ph- } \\
\text { age }\end{array}$ & Bact. & $\begin{array}{l}\text { Bact. } \\
+ \text { ph- } \\
\text { age }\end{array}$ & $\begin{array}{l}\text { Bact. } \\
\text { per se }\end{array}$ & $\begin{array}{l}\text { Bact. } \\
+ \text { pb } \\
\text { age }\end{array}$ & *- $\begin{array}{l}\text { Bact. } \\
\text { per se }\end{array} \mid$ & & $\begin{array}{l}\text { Bact. } \\
+ \text { ph- } \\
\text { age }\end{array}$ & $\begin{array}{l}\text { Bact. } \\
\text { per se }\end{array}$ & $\begin{array}{l}\text { Bact } \\
+ \text { ph } \\
=g e\end{array}$ & $\begin{array}{l}\text { Bact. } \\
\text { per se }\end{array}$ & $\begin{array}{l}\text { Bact: } \\
+ \text { ph } \\
\text { age }\end{array}$ & $\begin{array}{l}\text { Bact. } \\
\text { per se }\end{array}$ \\
\hline A & 0 & 1 & 3 & 4 & 4 & 5 & $\mathrm{~J}$ & 0 & 1 & 2 & 3 & 2 & 3 \\
\hline B & 0 & 1 & 2 & 4 & 4 & 4 & $\mathrm{~K}^{\prime \prime}$ & 0 & 1 & 0 & 3 & 1. & 4 \\
\hline $\mathrm{C}$ & 0 & 1 & 2 & 4 & 4 & 5 & $M$ & 0 & 1 & 2 & 3 & 3 & 3 \\
\hline D & 0 & 1 & 1 & 3 & 2 & 3 & $\mathrm{~N}$ & 0 & 1 & 2 & 3 & 3 & 3 \\
\hline $\mathrm{E}$ & 0 & 1 & 1 & 3 & 3 & 3 & $\mathrm{O}$ & 0 & 1 & 2 & 4 & 3 & $t$ \\
\hline $\mathrm{F}$ & 0 & 1 & 1 & 2 & 3 & 4 & $\mathrm{P}$ & 0 & 1 & 2 & 3 & 3 & 4 \\
\hline $\mathrm{G}$ & 0 & 1 & $I$ & 3 & 2 & 3 & $Q$ & 0 & 1 & 2 & 4 & 4 & $\tilde{5}$ \\
\hline $\mathrm{H}$ & 0 & 1 & 2 & 5 & 4 & 5 & $\mathrm{~s}$ & 0 & 1 & 2 & 5. & 4 & 5 \\
\hline I & 0 & 1 & 3 & 4 & 4 & 4 & $T$ & 0 & 1 & 1 & 4 & 4 & 4 \\
\hline
\end{tabular}

B. 24 時間唔養にファーデニを接種せる塂合 


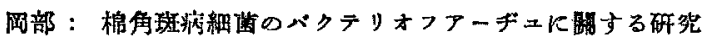

第 5 表 No. 450 菌の彎異菌の 24 時間 potato. dextrose solution ハフフーデュ势接擂せる埸合

Tab. 5. Phagic activity against the 24 hour-potato dextrose solutions of No. 450-variants.

\begin{tabular}{|c|c|c|c|c|c|c|c|c|c|}
\hline \multirow{3}{*}{ Type } & \multicolumn{4}{|c|}{ Turbidity of cultures } & \multirow{3}{*}{ Type } & \multicolumn{4}{|c|}{ Turbidity of cultures } \\
\hline & \multicolumn{2}{|c|}{ After 24 hours } & \multicolumn{2}{|c|}{ After 3 days } & & \multicolumn{2}{|c|}{ After 24 hours } & \multicolumn{2}{|c|}{ After 3 days } \\
\hline & $\begin{array}{l}\text { Bact. }+ \\
\text { phage }\end{array} \mid$ & $\begin{array}{l}\text { Bact. } \\
\text { per se }\end{array}$ & $\left|\begin{array}{l}\text { Bact. }+ \\
\text { phage }\end{array}\right|$ & $\begin{array}{l}\text { Bact. } \\
\text { per se }\end{array}$ & & $\begin{array}{l}\text { Bact. }+ \\
\text { phage }\end{array}$ & $\begin{array}{l}\text { Bact. } \\
\text { per se }\end{array}$ & $\left|\begin{array}{l}\text { Bact. }+ \\
\text { phage }\end{array}\right|$ & $\begin{array}{l}\text { Pact. } \\
\text { per se }\end{array}$ \\
\hline$A$ & 1 & 3 & 3 & 5 & J & 1 & 2 & 1 & 3 \\
\hline $\mathbf{B}$ & 1 & 4 & 3 & 4 & $\mathrm{~K}$ & 0 & 1 & 2 & 3 \\
\hline $\mathrm{C}$ & 1 & 4 & 3 & 5 & $\mathbf{M}$ & 1 & 2 & 1 & 4 \\
\hline $\mathrm{D}$ & 1 & 3 & 2 & 4 & $N$ & 2 & 3 & 3 & 4 \\
\hline $\mathrm{E}$ & 1 & 3 & 1 & 3 & 0 & 0 & 3 & 2 & 4 \\
\hline $\mathrm{F}$ & 1 & 3 & 2 & 5 & $\mathrm{P}$ & 2 & 4 & 3 & 5 \\
\hline $\mathrm{G}$ & 1 & 2 & 1 & 3 & $Q$ & 1 & 4 & 3 & 5 \\
\hline $\mathrm{H}$ & 1 & 4 & 3 & 5 & $\mathrm{~S}$ & 1 & 4 & 9 & 5 \\
\hline I & 1 & 4 & 4 & 5 & $\mathrm{~T}$ & 2 & 4 & 3 & 5 \\
\hline
\end{tabular}

液體培養基に柆ては No. 427 の各變異菌は何れもフアーヂュの作用を受け ない。之に反し No. 450 の菌は第4及び 5 表に示す如く，多少變異菌によつ てその程度は異るも，いづれも溶菌作用を受ける。然し何れの場合に於ても培 盖基中に存在する細菌を凡て溶解死減せしめ，培養液を永久に透明ならしめる


狀態となる。

\section{C. 固形唔菱基を使用せる場合}


後 5cc 大の殺菌水に浮游せしめ，何九も同一の turbidity たらしむ。然る後 是等の液を夫夫ペトリ一皿に5滴宛滴下し，直ちに豫め稀釋して用意せるファ 一ヂ二液を1滴加人，又溶解して $50^{\circ} \mathrm{C}$ に保てる potato dextrose agar を

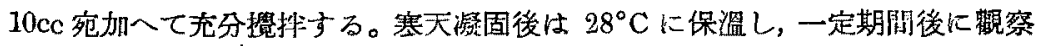
した。是の結果の一つを示すと第6 表の如くである。但し No. 427 菌を使用 した場合は何れも溶菌斑の形成がないから，No.427 の變異菌はフアーデュの 作用を全然受けざるのと考入られる。 




Tab. 6. Plaque formation of the phage against No. 450-variants.

\begin{tabular}{|c|c|c|c|c|c|c|c|}
\hline \multirow{2}{*}{$\begin{array}{c}\text { Types } \\
\text { of } \\
\text { variants }\end{array}$} & \multirow{2}{*}{$\begin{array}{c}\text { Number } \\
\text { of } \\
\text { plaques }\end{array}$} & \multicolumn{3}{|c|}{ Diameter of plaques, after } & \multicolumn{3}{|c|}{ Cbaracter of plaques } \\
\hline & & $\begin{array}{c}24 \text { hours } \\
\mathrm{mm}\end{array}$ & $\begin{array}{c}3 \text { days } \\
\mathrm{mm}\end{array}$ & $\begin{array}{c}5 \text { days } \\
\mathrm{mm}\end{array}$ & Size & Margin & $\begin{array}{l}\text { Grade of } \\
\text { clearness }\end{array}$ \\
\hline A & 250 & 0.5 & do & do & small & indistinct & wealk." \\
\hline $\mathrm{B}$ & 240 & 0.5 & do & do & small & indistinct & weak \\
\hline $\mathrm{C}$ & 240 & $0 . \tilde{5}$ & do & do & small & indistinct & weak \\
\hline $\mathrm{D}$ & 290 & $1.0-3.5$ & $2.5-5.0$ & do & medium & distinct & medium \\
\hline $\mathrm{E}$ & 9 & $1.0-30$ & $4-6$ & $6-9$ & large & distinct & stro"g $\mathrm{g}$ \\
\hline$F$ & 248 & $1.0-1.5$ & $2-3.5$ & do & medium & indistinct & weak \\
\hline $\mathrm{G}$ & 221 & $0.8-2.8$ & do & do & medium & indistinct & weals \\
\hline $\mathrm{H}$ & 251 & $1.0-9.5$ & do & do & medium & distinct & medium \\
\hline I & 265 & $1.0-1.5$ & $2-3$ & đo & medium & indistinet & weak \\
\hline $\mathrm{J}$ & 3 & $1.0-25$ & $5-7$ & $9-13$ & large & distinct & strong \\
\hline $\mathrm{K}$ & 235 & $1.2-3.5$ & do & do & medium & distinct & medium \\
\hline L & 251 & $0.5-2.5$ & $1.5-4.0$ & $3-7$ & large & distinet & strong \\
\hline M & 2 & $1.5-3.0$ & $4.5-7.0$ & $9-11$ & large & distinet & strong \\
\hline$N$ & 248 & $0.5-2.8$ & do & do & medium & indistinct & weak \\
\hline 0 & 3 & $1.5-3.0$ & $2.5-5.0$ & $3.5-7$ & large & distinet & strong \\
\hline $\mathrm{P}$ & 2 & $1.5-3.0$ & $3.5-6.5$ & $3.5-6.5$ & large & distinct & strong \\
\hline$Q$ & 216 & $0.5-1.0$ & $0.5-2.5$ & do & medium & indistinct & weak \\
\hline $\mathrm{R}$ & 250 & $1.0-1.5$ & $1.5-3.0$ & do & medium & indistinet & weak \\
\hline 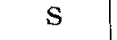 & 223 & $0.5-2.5$ & $0.5-3.2$ & $1.0-4.0$ & medium & distinct & strong \\
\hline $\mathrm{T}$ & 250 & $0.8-2.5$ & $1.0-3.0$ & $1.0-4.0$ & medium & distinct & strong \\
\hline $\mathrm{U}$ & 264 & $0.5-2.5$ & do & do & medium & indistinct & medium \\
\hline $\mathrm{V}$ & 255 & $0.5-2.0$ & do & do & medium & indistinct & weak \\
\hline W & 235 & $1.0-2.2$ & $1.0-2.5$ & do & medium & indistinct & weak \\
\hline
\end{tabular}

本研究に使用せるフアーヂニは上迅の如くNo. 450 菌に作用するす No. 427 菌には作用せす，從つて Bact. malvacearum の同一種中にもフアーギュに對 して異なる行動を採る系統の存在することを知ると同時に; 又今日迄報告され て居る植物病原菌のフフーギニと異故り高度の特異性を有するすのと認める。 
No. 450 の各變異菌に對しては，其作用は滩體培養基に於けるょりも固形培 䓹基に於て著しく明瞙に現れ，形咸された溶菌玟の数，大きさ，溶菌の程度等 に夫ふ差異のあることを知る。先づ溶菌斑の数に就いて見るに, E, J, M, O, P の各稤異菌を使用せる場合は，他の變異菌を使用せる場合に比して著しくその 數が隇少して居る。文大きさは種々なる保件によつて多少の變化はあるが，大 體に大，中，小の3 種類に分つことが出來る。大型溶菌斑を形成する菌は $\mathrm{E} ， \mathrm{~J}$,

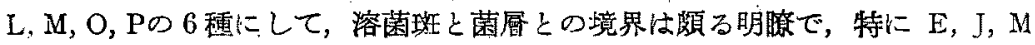

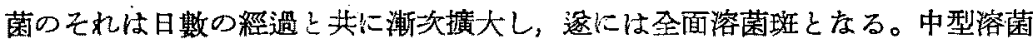
斑は一般に初期に擴大するのみで，菌屡との境界は明瞭なるものと然らざるも のとがあり，溶菌作用は $\mathrm{S}$ 及び $\mathrm{T}$ 菌のみ强く，他は强くない。小型溶菌斑は A， B，及び C の三菌に沾て見られ，是等は日数の經過につれ菌首の發育によ り潮次不明瞭となる傾向がある。

以上の如く No. 450 菌の變異菌は夫みフアーヂニに作用せしむると唓なる 結果を示すが，是が原因は各變異菌によりフアーヂニに對する感受性が異なる 點もあらうが，溶菌斑數の著しく相違する點上り見て，フアーヂ二夫れ自身に

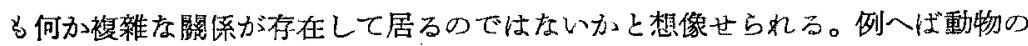
腸內細菌の或フアーヂニには溶菌斑の大きさにより数種の elemental phage の存在することが知られて居る樣に，著者の場合にも恐らくはか〉るフフーヂ ユが存在するのではなからうかと考へて，㳄に逝へ后樣な方法で elemental phage の分離を行つた。

III. Elemental phage に關する研究

\section{A. 分離の方法}

溶菌斑の大きさ，性狀はフア゙ーデュの喠類を让定するのに重大なる要素の一 つである。從つて第 6 表に示すが如き數種の異なる溶菌斑の存在はこのフアー デニの單一種でないことを暗示するすのであると想像される。それで出來るた け代㞷的な數稙つ溶菌斑を一つ宛，各风別そに殺菌せる白金線にて寒天もると b釣取し potato dextrose solut:on に加八て破碎し, 同時に夫ょの篎異菌を

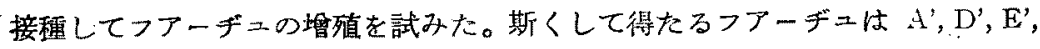
$\mathrm{J}, \mathrm{O}^{\prime}$ 及び $\mathrm{S}^{\prime} の 6$ 種にして，是等は夫火 $\mathrm{A}, \mathrm{D}, \mathrm{E}, \mathrm{J}, \mathrm{O}, \mathrm{S}$ の各藏にフアー 
ヂュ在作用せしめて得たる單一溶菌斑より分觊せるものである。

\section{B. Elemental phage.}

上記 6 種のフフーヂュを夫ネ互に 6 種の變異菌に作用せしめたるに次表の如 き結果を得た。

第 7 表 各種フアーギュの綧異菌に對する作用

Tab. 7 . Activity of several phages against the variants of No. 450 .

\begin{tabular}{|c|c|c|c|c|c|c|}
\hline Bact. Phage & $A^{\prime}$ & $D^{\prime}$ & $\mathbf{E}^{\prime}$ & $\mathrm{J}^{\prime}$ & $O^{\prime}$ & $\mathbf{S}^{\prime}$ \\
\hline $\mathrm{A}$ & + & + & + & + & + & + \\
\hline$D$ & + & + & + & + & + & + \\
\hline E & - & - & + & + & + & - \\
\hline $\mathrm{J}$ & - & - & + & + & + & - \\
\hline 0 & - & - & + & + & + & $\rightarrow$ \\
\hline $\mathrm{S}$ & + & it & + & + & + & + \\
\hline
\end{tabular}

$+=$ positive, $-=$ gegative

此の表より本フアーヂュは $\mathrm{E} ＼textrm{J} ＼textrm{O}$ 菌等に作用するものとせざるるのとの 2 種よりなることが知られる。E'，J'皮び $\mathrm{O}^{\prime}$ フアーヂュは凡ての變異菌に 對して作用するが， $\mathrm{A}^{\prime} ， \mathrm{D}^{\prime}, \mathrm{S}^{\prime}$ 等のフアーギュは $\mathrm{E}, \mathrm{J}, \mathrm{O}$ 菌に對して作用し ない。此の結果を第 6 表の成縝と合せて考へるに，元來原フアーギュは上記 2 種のフアーデ二の混合より成り，E，J，M，O,P囷に作用し得る elementa1 phage を少鹳含むと同特に，他の全部の變異菌に對して作用する elemental phageをも多數に含むものと推察される。これが溶菌斑形成數に著しき差を生 ぜる原因で，溶菌琣の性狀の使用世る菌型に上つで異なる所以は，菌型に 上り憼受性を異にする胥であらう。依つて得たる elemental phagaを凡ての 戀異菌に作用せしめ，形成された溶菌甠の大きさ，数，性狀等を調查して，此 の考の正否を知らんと試みた。その結果の一つを示すと次表の如くである。

Elemental phage $A$ を使用せる場合梳第 8 表の示す如く第 6 表の結果々は 多少異つて居る。溶菌斑の数は稍ぬ不同ではあるが，大體近似して居り，E，J， M，O 及び P 菌に溶菌作用を示して居らない。文溶菌斑は一般に小さく溶 菌作用は强くない樣である。Elementa1 phage J’を作用せしめたる場合は $\mathrm{A}^{\prime}$ フアーヂ亡の作用をしない $\mathrm{E}, \mathrm{J}, \mathrm{M} ， \mathrm{O}$ 及び P 菌に作用を有する以外に大 した相違は見出せない。フアーヂュに龂する感受性の强弱は，形威された溶菌 斑の大きさ，擴大性の有然，溶菌の程度等に依つて推察することが出來るが，及 


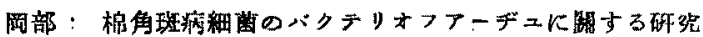

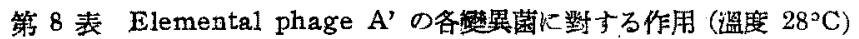

Tab. 8. Activity of elemental phage $A^{\prime}$ against the variants of No, 450 .

\begin{tabular}{|c|c|c|c|c|c|c|c|}
\hline \multirow{2}{*}{$\begin{array}{c}\text { Types } \\
\text { of } \\
\text { variants }\end{array}$} & \multirow{2}{*}{$\begin{array}{c}\text { Number } \\
\text { of } \\
\text { plaques }\end{array}$} & \multicolumn{3}{|c|}{ Diameter of plaques,after } & \multicolumn{3}{|c|}{ Characters of plaques } \\
\hline & & $\begin{array}{c}24 \text { hours } \\
\mathrm{mm}\end{array}$ & $\begin{array}{c}3 \text { days } \\
\mathrm{mm}\end{array}$ & $\begin{array}{c}5 \text { days } \\
\mathrm{mm}\end{array}$ & Size & Margin & $\begin{array}{l}\text { Grade of } \\
\text { clearness }\end{array}$ \\
\hline A & 75 & 0.5 & do & do & small & indistinct & weak \\
\hline $\mathbf{B}$ & 76 & 0.5 & 0.5 & 0.5 & small & indistinct & weak \\
\hline $\mathrm{C}$ & 86 & $0.2-0.8$ & do & do & small & indistinct & weak \\
\hline $\mathrm{D}$ & 75 & $0.5-3.0$ & do & do & medium & distinct & medium \\
\hline $\mathbf{E}$ & 0 & & & & & $\cdot$ & \\
\hline $\mathbf{F}$ & 82 & $1.0-1.5$ & $2-3.5$ & do & medium & indistinct & weak \\
\hline G. & 59 & $1.0-2.5$ & do & do & medium & indistinct & weak \\
\hline $\mathrm{H}$ & 62 & $0.5-1.5$ & $0.5-2.0$ & do & medium & distinet & medium \\
\hline I & 74 & $1.0-1.5$ & $2-3$ & do & medium & indistinct & weak \\
\hline J & 0 & & & & & & 1 \\
\hline $\mathrm{K}$ & 85 & $1.2-3.5$ & do & do & medium & distinct & mediam \\
\hline $\mathrm{L}$ & 54 & $1-2.5$ & do & do & medium & indistinet & weak \\
\hline M & 0 & & & & & & \\
\hline$N$ & 72 & 0.2 & 0.5 & do & small & indistinct & weak \\
\hline $\mathrm{O}$ & 0 & & & & & & \\
\hline $\mathrm{P}$ & 0 & & & & & & \\
\hline$Q$ & 96 & 0.5 & do & do & small & indistinet & weak \\
\hline $\mathrm{R}$ & 95 & $1.0-2.8$ & $1.2-3.0$ & do & medium & distinct & medium \\
\hline $\mathbf{S}$ & 94 & $0.5-3.0$ & $1.0-3.5$ & do & medium & distinet & medium \\
\hline $\mathrm{T}$ & 76 & $0.5-1.5$ & do & do & small & indistinct & weak \\
\hline$\cdot \mathbf{U}$ & $13 \pm$ & $0 . \overline{5}-1.5$ & do & do & small & "in is:inct & weak \\
\hline $\mathrm{V}$ & 86 & $0.2-0.8$ & do & do & small & indistinct & weak \\
\hline W & 84 & $0.5-1.5$ & do & do & small & indistinct & weak \\
\hline
\end{tabular}

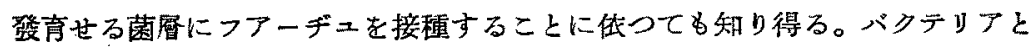
フアーヂニを混合後直ちに potato dextrose agar に plate $c: 1$ ture する時 は溶菌斑は明瞕且つ容易に形成されるものであるが，数時間涇過せる後フフー デュを接璉せる場合は一般に形成されないか，或は不明瞭になる傾向がある。 
及感受性の大なる湅菌程，溶菌作用は細菌の發育程度に左右されることが少い。 依つて potato dextrose agar に豫め各變異菌を加人 plate culture をなし18 時間及び 24 時間後にフアーヂュを接程して溶菌作用を受けたるや否やを調へ て見た。此の結果に体ると，18時間後にては其の程度に差はあるが，殆ど全部 の變異菌が溶菌作用を受けて居る。小型溶菌斑を形成する變異菌は中型溶菌班

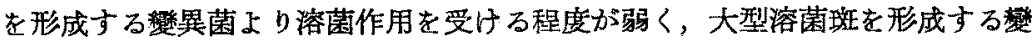
異菌は最も高い透明度を示して居る。24時間後の場合には D， E，J，Mの4菌 にのみ現れ， $\mathrm{K} ， \mathrm{O}, \mathrm{P}, \mathrm{S}$ の4菌には極めて僅に見られるのみである。是より 最もフアーヂュの作用を受け易い變異菌は D, E, J, M で, 次いで $\mathrm{K}, \mathrm{O}, \mathrm{P}, \mathrm{S}$ であると云ふことが出來る。台フアーヂニががつる發育せる細菌に働いて溶菌 作用を現すには titre の强弱が非常に閵係するので，上迅の賽驗には titreの 高い A'フアーヂュ，及び J'フアーヂュを使用した。titre の弱いフアーヂ ユを使用した場合は何れも negativeに終つた。

\section{C. ファーヂュと溫度との關係}

Elemental phage $A^{\prime}$ 及び J'を以て溶菌斑の數，大きさと溫度の關係を知 るために次の如き方法により賽驗を行つた。供試菌は感受性强き J 型菌及び弱 き $\mathrm{A}$ 型菌で，是等の 24 時間肉汁寒天科面培養を殺菌水にて浮游せしめ各及5㵜 宛をぺトリ皿に入れ，同時に一定漫度のブアーヂニを 1 滴宛滴下し，常法に依つ

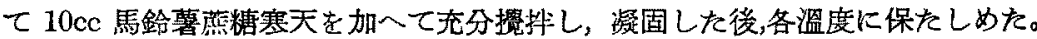

第 9 表 ファーヂュと㵋度との關係（A 菌にA'ファーヂニを作用せしめたる埸合）

Tab. 9. Temperature relation (A' phage against variant $A$ )

\begin{tabular}{c|c|c|c|c}
\hline \multirow{2}{*}{$\begin{array}{c}\text { Temperature } \\
{ }^{\circ} \mathrm{C}\end{array}$} & \multicolumn{2}{|c|}{ After 24 hours } & \multicolumn{2}{c}{ After 48 hours } \\
\cline { 2 - 5 } & Number & $\begin{array}{c}\text { Size } \\
\mathrm{mm}\end{array}$ & Number & $\begin{array}{c}\text { Size } \\
\mathrm{mm}\end{array}$ \\
\hline $34^{\circ}$ & 137 & $0.2-0.5$ & 137 & $0.2-0.5$ \\
\hline $31^{\circ}$ & 762 & 0.5 & 764 & $0.5-0.8$ \\
\hline $28^{\circ}$ & 1360 & 0.5 & 1368 & $0.5-0.3$ \\
\hline $25^{\circ}$ & 1280 & $0.5-0.8$ & 1285 & $0.5-1.0$ \\
\hline $22^{\circ}$ & 1250 & 0.5 & 1256 & $0.5-1.0$ \\
\hline $19^{\circ}$ & 1190 & 0.5 & 1192 & $0.5-1.0$ \\
\hline $16^{\circ}$ & 980 & 0.5 & 989 & $0.5-1.0$ \\
\hline
\end{tabular}




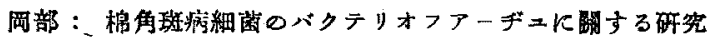

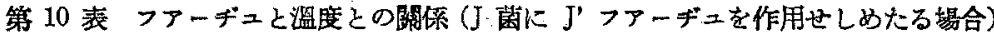

Tab. 10. Temperature relation (J' phage against variant $\mathrm{J}$ )

\begin{tabular}{|c|c|c|c|c|c|c|}
\hline \multirow{2}{*}{$\begin{array}{c}\text { Temperature } \\
{ }^{\circ} \mathrm{C}\end{array}$} & \multicolumn{2}{|c|}{ After 24 hours } & \multicolumn{2}{|c|}{ After 3 days } & \multicolumn{2}{|c|}{ After 6 days } \\
\hline & Number & $\begin{array}{l}\text { Size } \\
\mathrm{mm}\end{array}$ & Number & $\begin{array}{l}\text { Size } \\
\mathrm{mm}\end{array}$ & Number & $\begin{array}{l}\text { Size } \\
\mathrm{mm}\end{array}$ \\
\hline 34 & 6 & $\frac{0.2-0.8^{\prime}}{(0.5)}$ & 6 & $\begin{array}{c}0.5-0.8 \\
(0.5)\end{array}$ & 6 & $\begin{array}{c}0.2-0.5 \\
(0.3)\end{array}$ \\
\hline 31 & 79 & $\begin{array}{c}0.5-2.5 \\
(2.0)\end{array}$ & 81 & $\begin{array}{c}0.5-2.5 \\
(2.0)\end{array}$ & 81 & $\begin{array}{c}0.5-2.5 \\
(1.8)\end{array}$ \\
\hline 28 & 108 & $\frac{0.8-2.8}{(2.5)}$ & 111 & $\begin{array}{c}0.8-3.5 \\
(3.0)\end{array}$ & 111 & $\frac{4.0-10.0}{(8.0)}$ \\
\hline 25 & 142 & $\begin{array}{c}0.8-2.5 \\
(2.2)\end{array}$ & 150 & $\begin{array}{c}1.2-4.0 \\
(3.5)\end{array}$ & 150 & $4.0-11.0$ \\
\hline 22 & 114 & $\begin{array}{c}0.8-2.2 \\
(2.0)\end{array}$ & 126 & $\underset{(4.0)}{1.5}$ & 126 & $\begin{array}{c}4.0-10.0 \\
(8.2)\end{array}$ \\
\hline 19 & 117 & $\begin{array}{c}0.5-2.0 \\
(1.5)\end{array}$ & 120 & $\begin{array}{c}1.5-4.2 \\
(3.8)\end{array}$ & 120 & $\begin{array}{c}2.0-8.0 \\
(6.2)\end{array}$ \\
\hline 16 & 102 & $\begin{array}{c}0.5-2.0 \\
(1.2)\end{array}$ & 107 & $\begin{array}{c}2.0-3.5 \\
(3.0)\end{array}$ & 107 & $\begin{array}{c}2.0-5.0 \\
(4.4)\end{array}$ \\
\hline 13 & - & $\ldots$ & 105 & $\begin{array}{c}1.0-3.0 \\
(2.5)\end{array}$ & 105 & $\begin{array}{c}1.5-4.8 \\
(4.2)\end{array}$ \\
\hline
\end{tabular}

（括坬内は平坞の大きさ京示す）

第 9 及び第 10 表に示す如く溫度と溶菌班の數と大きさとの䦦には明らかに

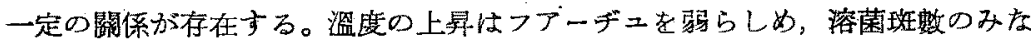
らす，形を小さくし，且溶菌作用を衰入させて居る。溫度の低い場合は假令人 数に於て多少の㟟はあるにしても，淿菌斑は明膫で溶菌作用の弱らさることを 示してわる。溶菌作用の最適溫鹿仙 $28^{\circ}-22^{\circ} \mathrm{C}$ の阴に存在する。

\section{D. 細囷の量と溶菌斑の閣係}

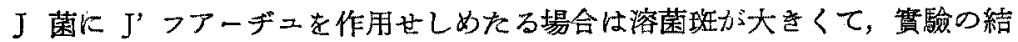
果を明瞭にするので，是を使用して菌量と溶菌壬の數，大きさとの關係を調へ

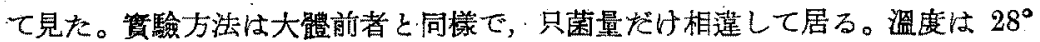
Cに保たした。此の結果は第 11 表の如くである。 


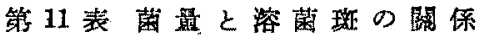

Tab. 11. Effect of the amount of bacteria on plaque formation.

\begin{tabular}{|c|c|c|c|c|c|c|}
\hline & \multicolumn{2}{|c|}{1 drop } & \multicolumn{2}{|c|}{2 drops } & \multicolumn{2}{|c|}{4 drops } \\
\hline & Number & $\begin{array}{c}\text { Diameter } \\
\mathrm{mm}\end{array}$ & Number & $\begin{array}{c}\text { Diameter } \\
\mathrm{mm}\end{array}$ & Number & $\begin{array}{c}\text { Diameter } \\
\text { mm }\end{array}$ \\
\hline After 24 hours & 138 & $\begin{array}{c}1.0-3.8 \\
(3.2)\end{array}$ & 131 & $\begin{array}{c}0.8-3.2 \\
(2.8)\end{array}$ & 129 & $\begin{array}{c}0.6-3.2 \\
(2.5)\end{array}$ \\
\hline After 2 days & 140 & $\frac{2.0-5.0}{(4)}$ & 133 & $\begin{array}{c}1.2-4.5 \\
(3.5)\end{array}$ & 130 & $\begin{array}{c}1.0-4.0 \\
(3.2)\end{array}$ \\
\hline \multirow[t]{3}{*}{ After 5 days } & do & $\frac{3.5-14}{(8.5)}$ & do & $\begin{array}{c}3.5-12 \\
(7.5)\end{array}$ & do & $\begin{array}{c}3.0-9.0 \\
(6.2)\end{array}$ \\
\hline & \multicolumn{2}{|c|}{8 arops } & \multicolumn{2}{|c|}{16 Drops } & \multicolumn{2}{|c|}{32 drops } \\
\hline & Number & $\begin{array}{c}\text { Diameter } \\
\mathrm{mm}\end{array}$ & Number & $\begin{array}{c}\text { Diameter } \\
\mathrm{mm}\end{array}$ & Number & $\begin{array}{c}\text { Diameter } \\
\text { mm }\end{array}$ \\
\hline After 24 hours & 118 & $\begin{array}{c}0.5-2.5 \\
(2.1)\end{array}$ & 109 & $\begin{array}{c}0.5-2.0 \\
(1.8)\end{array}$ & 96 & $\begin{array}{c}0.5-1.8 \\
(1.5)\end{array}$ \\
\hline After 2 days & 120 & $\underset{(2.8)}{0.8-3.5}$ & 111 & $\underset{(2.2)}{0.6-2.8}$ & 98 & $\underset{(1.8)}{0.5-2.2}$ \\
\hline After 5 days & do & $\begin{array}{c}2.5-7.5 \\
(5.0)\end{array}$ & do & $\begin{array}{c}2.5-7.0 \\
(4.5)\end{array}$ & do & $\begin{array}{c}2.0-6.5 \\
(4.2)\end{array}$ \\
\hline
\end{tabular}

（括坬內恃平均の大きさ）

溶菌斑の大きさ及び数は溫度の影響を非常に蒙るが，更に使用せる菌是によ つても獎代して來るもので，一般に或限界はあるけれど，菌量の少いるの程大

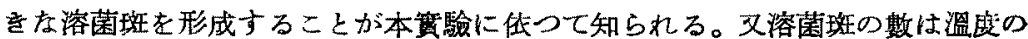
場合の樣に著しい差巽は示さはいが，菌量の增加に依つて㴬次減少して居る。

IV. ファーヂユ抵抗性菌の Colony form.

第 3 表乃至引表の示す如く，各菌にフアーヂュを作用せしむると，初めの間

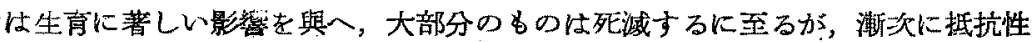

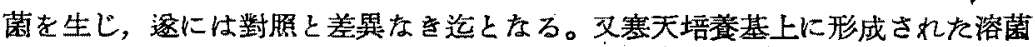
斑について見るも，日数の經過するにつれ濑次中央部上り抵抗性菌の出現する を認める。是等の菌種が果して如何なる Colony form を有するかと云ふ點は 又興味あることで，次の如を方法によつて分解を在し，Colony form を調へ ると同時に，フアーデェとの閵係を研究した。Potato dextrose solution に各

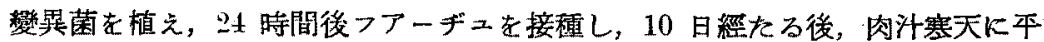




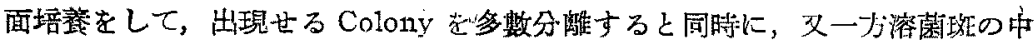

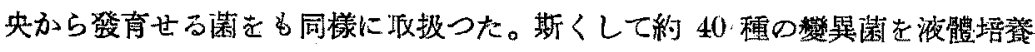
基より，23種の變舆菌を溶菌斑より分離したが，是等は凡てフアーギニの作䏹

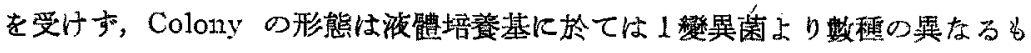
のを得られたが，溶菌斑よりは夫及の菌と同一の形熊を有するColony のみを

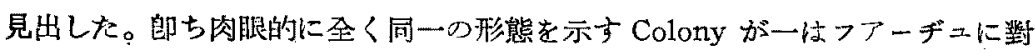
して感受性で一は抵抗性なる事を知つた。

\section{V. 總一括}



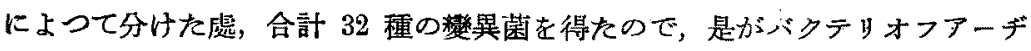
ニとの關係を研究した。No. 427 の 變異菌は凡てフアーヂニの作用を受けす， No. 450 の 23 變畟菌は凡て感受性ではあるが，其程度には夫々差がある。感

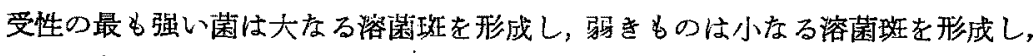

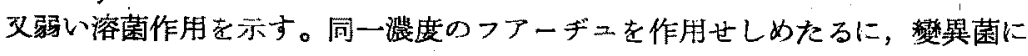
より出現する溶菌斑つ数菜しく減少さるものがある。依つて是が原因を研究せ るに,フアーヂニに2 種類の elemental phage の存在すること䓡つた。勘 ち凡ての變異菌に作用するフフーヂニと E，J，M，O 及び P 菌に作用せさる

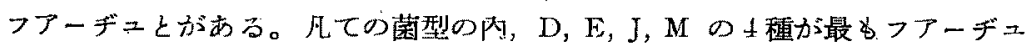
の作用を受け易い。E，J，M 菌に作用せしぬた場合は溶囷玟は日數の經迫 そ 共に潮次䭫大して非常に大きなる。溶菌斑の大きさは是が检出に使用せる菌 型の種類により著しく異なるが，其他細自の量，寒天の漫度，フアーヂュの

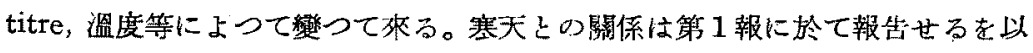
て，菌量及び溫度の關係を溶菌斑の坦減と併せて研究した。其の結果に作ると，

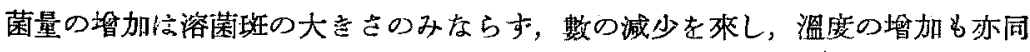

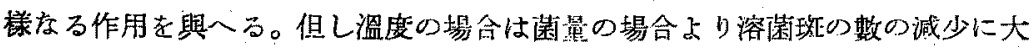
なる影響をあたへる。フアーヂ二抵抗泩菌を波體唔養基及び溶菌玫より多数分 㫿せるが，前者に於ては 1 菌型より政種つ抵抗性菌を生じ，後者上りは同一形 熊の些抗性菌のみが生じた。抵抗性菌は形態的には弪く感受性菌と區则するこ とが出來ない。 


\section{引用文 獻}

1. EvelyN, S. H. Mycological work-Ann. Report. Dept. of Agric Barbados for the year 1926-27. p. 15. 1928. (R. A. M. $8: 20$ )

2. MASSEY, R. E. Studies of Blackarm Diseases of Cotton II. The Empire Cotton Growing Review 8: 1-27, 1931 .

3. Sections of Botany and Plant Patbology. G. A. R. S. Final Report on experimental work in 1932-33. Ann. Rept. Gezira Agric. Res. Serv. for the year ended 31 st. December, 1933. pp 126-146, 1934 (R. A. M. 13: 696)

4. Matsumoto, T. \& HuziokA, Y. Bacteriophage in relation to Bact. malvacearum E. F. S. I. Preliminary Study. Ann. Phytopath. Soc, of Japan $7: 193-202,1938$

5. Smith, E. F. Bacterial Diseases of plants. pp. 314-339, 1920.

6. Stoughton, R. H. Angular Leaf-spot of Cotton. Nature 125: $350-351$, 1930.

7. Rothamstead Experimental Station Report for 1931, p. 199. 1932 (R. A. M: $12: 141$ )

\section{Résumé}

Thirty-two colony variants were obtained from the two different strains of Bacterium malvacearum which were isolated from the angular spots of cotton at Taihoku; viz. 9 variants (A-I in fig. 1 ) from culture strain 427 and 23 variants (A-W in pl. II) from culture strain 450. All the variants derived from the former are resistant to the phage which was isolated from the diseased leaves by MATSUMOTO and HUzIOKA, ${ }^{(4)}$ while any of the latter are susceptible to it, though somewhat different in susceptibility and size.of plaque produced, generally more susceptible variants producing larger plaques (table 6). The plaques produced on the cultures of variants $E$, $J$, and $M$ enlarge to a graat extent with the increase of the incubation period (table 6). The phage in question proved to be consisted of at least two elemental phages. The one is active against all the variants, and the other is only active against those except $\mathrm{E}, \mathrm{J}, \mathrm{M}, \mathrm{O}$, and $\mathrm{P}$ variants (tables 7-8). The size and number of plaques are more or less decreased with the increase of the amount of bacteria used (table 11). The same is true with the temperature within a certain limit, although in this case the effect is more remarkable on the number of plaques. Resistant strains developed from the phage-bacterial cultures are not apparently different in morphological characters from their original susceptible bacteria. 


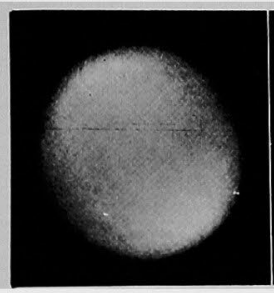

A

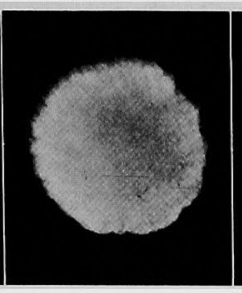

B



C

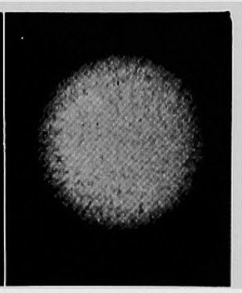

D


第 II 圖 版棉角斑病菌の肉汁寒天上に於ける形態 Culture No. 450 . 